\title{
The strategic role of Board of Commissioners in Resource-Based View approach and Agency Theory perspectives to attain sustainable competitive advantage in the Indonesian Banking Industry \\ Andre M. Hartawan, Yuswar Z. Basri, Willy Arafah \\ Corresponding Author: Andre M. Hartawan
}

\begin{abstract}
As Board of Commissioner $(\mathrm{BoC})$ is one of the most important internal corporate governance mechanisms used by the shareholders to monitor management, this study endeavors to develop and test a conceptual model to enable the BoC to function as the Bank's strategic resources, addressing agency dynamics in agency theory perspective which eventually will lead to sustainable competitive advantage in the Indonesian Banking Industry.
\end{abstract}

The study focuses on the perceived knowledge of the Indonesian Bank's current BoC members where data were collected through questionnaire with Structural Equation Modeling (SEM) analysis. The sampling technique is purposive sampling method collected from 97 Commissioners in Indonesian Banks within category 1 to 3.

The research reveals following findings: (i) The effect of Board Member Attributes on BoC performance in Resource-Based View (RBV) is positive and significant (ii) The effect of Board Attributes on BoC performance in RBV is positive and significant (iii) The effect of Information Access and Disclosure on BoC performance in RBV is positive and significant (iv) The effect of Information Access and Disclosure on Sustainable Competitive Advantage is positive and significant (v) The effect of BoC in RBV on Sustainable Competitive Advantage is positive and significant (vi) The effect of BoC in RBV on Agency Dynamics is positive and significant (vii) The effect of the Agency Dynamics on Sustainable Competitive Advantage is insignificant and negative (viii) The mediating effect of BoC in RBV can increase the effect of Information Access and Disclosure on Agency Dynamics mitigation (ix) The mediating effect of BoC in RBV can increase the effect of Information Access and Disclosure on Sustainable Competitive Advantage ( $x$ ) The mediating effect of BoC in RBV can increase the effect of Board Member Attributes on Sustainable Competitive Advantage (xi) The mediating effect of BoC in RBV can increase the effect of Board Attributes on Sustainable Competitive Advantage.

Based on empirical findings obtained in this research, the managerial implications of this research can be used as input for Indonesian Bank's relevant stakeholders to improve the quality of Board Member Attributes, Board Attributes, Information Access and Disclosure, in optimizing strategic role BoC in RBV, in mitigating Agency Dynamics towards achieving the Bank's Sustainable Competitive Advantage.

Keywords: Corporate Governance, Resource-Based View, Agency Theory, Board of Commissioners, Independent Commissioner, Information Access and Disclosure, Sustainable Competitive Advantage

\section{Introduction}

Indonesia has over 250 million population and the fourthlargest economy in Asia. This has made Indonesia as one of the world's biggest potential Banking markets. Growth in profitability, loans and assets has been stronger than in other ASEAN countries, although an economic slowdown in 2015 and early 2016 curbed sector growth before an upswing in 2017 (Oxford Business Group, 2018). The Indonesian market has historically been - and continues to be - highly profitable in comparison to more developed economies. The Banking sector still offers plenty of untapped potential and room for competition, leaving opportunities for higher margins and new product development. This can be observed from
Hamada's (2018) study that Indonesia's Banking sector is small in terms of the size of the country's real economy where credit provided by the Banking sector in terms of percentage of Indonesia's gross domestic products (GDP) remains low (around 36 per cent in 2016), and access to the finances of small and medium enterprises (SMEs) is limited. Looking at this attractive potential as well as market and macro economy challenges in the Indonesian Banking Industry, Faulkenberry (2020) suggested the importance of sustainable competitive advantages for a company to thrive in navigating those challenges.

After the 1998 financial crisis, one of the main programs of revitalization of Indonesian Banks was the implementation of 
the Indonesian Banking Architecture which was launched by Bank Indonesia on January 9, 2004. Main aspect underlying this Architecture is the weak Banking capacity as characterized by a lack of corporate governance and core Banking skills in most of the Banks, where required remedies are crucial (Lutfi et al, 2012).

Lutfi et al, (2012) further stated that considering this problem, one of the six pillars of the Indonesian Banking Architecture program is creating Good Corporate Governance to strengthen the internal condition of the Indonesian Banking system. Since 2006 until today, Bank Indonesia has issued various regulations with a view to improve the corporate governance of Indonesian Banks.

The broader objectives of corporate governance are: to protect the interests of shareholders and various other stakeholders including customers, suppliers, employees and society at large, to ensure full transparency and integrity in communication and to make available complete, accurate and clear disclosure to all concerned (Madhani, 2017).

Thus logically, better implementation of good corporate governance supported by a reliable operational capability is expected to improve the operational performance of Banks and this is related to Madhani (2007) where he stated that Corporate Governance stands for responsible business management geared towards long-term value creation. Good corporate governance is a key driver of sustainable corporate growth and long-term competitive advantage. Madhani (2014) further mentioned that Good governance means little expropriation of corporate resources, which contributes to better allocation of resources and better performance.

Based on this situation, it can be agreed that Good Corporate Governance (GCG) will contribute to improve Bank's performance and this argument also supported by Peni \& Vahamaa (2011) which documented that Banks with strong corporate governance practices had substantially higher stock returns in the aftermath of the market meltdown, indicating that good governance may have mitigated the adverse influence of the crisis on Bank credibility.

Referring on research conducted by the Indonesian Banking Development Institute (LPPI), for 10 years since 2007, the composite value of the implementation of GCG by the Banking industry is still in good condition. However, this value seems to deteriorate and reach its peak in 2015. Simatupang (2018) revealed, in 2011-2015 the Banking industry faced a problem, related to the rampant fraud in several commercial Banks.

The latest accounting scandal by Deloitte, top 4 public auditor in Indonesia where they released a sound audit result of PT Sunprima Nusantara Pembiayaan (SNP), a financial services subsidiary of the Columbia group, which has more than 30 years' experience in trading and financing electronic goods and furniture, is undergoing a court-enforced suspension of debt payments to buy time for an amicable settlement with its creditors and to avoid bankruptcy and liquidation. This has impacted its creditors and investor of its bonds, consisted of 14 Banks to suffer a potential loss of up to Rp 2.4 Trillion. Other instances in the global scale, accounting scandals in the US corporate world such as Enron and WorldCom have sparked debates on the integrity of corporate financial reporting where its widespread failure in financial reporting has largely been blamed on weak corporate governance mechanisms (Rahman, 2006).

An important corporate governance aspect is the duties and responsibilities of Boards of Directors, or in a two-tier governance system country such as Indonesia known as Board of Commissioners (BoC). In conjunction to Madhani (2009) statement where good governance practices provide a sustainable competitive advantage, Madhani (2017) stated that the outcome of a good corporate governance practice is an accountable $\mathrm{BoC}$ who ensures that the investors' interests are protected and further mentioned that $\mathrm{BoC}$ is one of the most important internal corporate governance mechanisms used by the shareholders to monitor management.

McNulty \& Pettigrew (1996) identified the various roles of $\mathrm{BoC}$ in terms of three main perspectives: 1. A governance perspective (the monitoring function of the board); 2. A strategic perspective (decisions enabling the firm to change), and 3 . The resource perspective (how the board links the firm to its external environment and enables it to acquire critical resources). In addition, four major roles and responsibilities of the board have been widely recognized by researchers: (1) the control role; (2) the strategic role; (3) the service or resource provision role; and (4) the advice and counsel role (Nicholson \& Kiel, 2004; and Bonn \& Pettigrew, 2009).

BoC have an oversight role and as such it oversees strategy and monitors the managerial decisions of the top management team (Harrison, 1987; Johnson et al., 1993 and 1996; and Withers \& Hillman, 2008). Research also states that BoC serve critical functions in firms, such as monitoring management on behalf of shareholders and providing valuable resources to firms, including advice, expertise, connections to environmental contingencies, and legitimacy (Hillman \& Dalziel, 2003). The strategic role of the BoC does not imply that the $\mathrm{BoC}$ engages in the strategy formulation, since it is the duty of the management. The strategic role of the $\mathrm{BoC}$ relates to supporting and leading the management in realizing the firm's mission and its goals by advising, improving and enhancing the discussion on strategic issues, in particular the strategic problem solving and decision making (Madhani, 2017).

Researches on corporate governance often distinguish between independent and non-independent commissioners (Lutfi et al, 2012). The existence of BoC who are competent 
and independent is expected to be able to better monitor and provide more valuable input in solving agency problems between owners and managers (Fama \& Jensen, 1983; Shleifer \& Vishny, 1997). Some researchers provide evidence that supports the effectiveness of $\mathrm{BoC}$ in improving the performance and value of the firm is influenced by the proportion of independent members (Weisbach, 1988; Rosentein \& Wyatt, 1990; Brickley et al., 1994).

Regarding the effectiveness of the BoC, several aspects of the board may be considered: board structure and board independence, functions of the board and the activities of board committees, access to information and general support for independent Commissioners, and Commissioners compensation and liability (Nam, 2004).

Another aspect to be added in functions of $\mathrm{BoC}$ aside from their duty as effective stewards and guardians of the company as elaborated above, not just in setting strategic direction and overseeing the conduct of business, but also in ensuring that the company conducts itself in compliance with laws and ethical values and maintain an effective governance structure to ensure the appropriate management of risk and level of internal controls apart from taking care of the stakeholder's interest (James \& Joseph, 2015).

In the basis of its strategic role, the resource-based theory approach will be employed to examine $\mathrm{BoC}$ as corporate Governance mechanisms specifically the ownership monitoring mechanism, internal control monitoring mechanism (board independence and board size), and regulatory mechanism (as regulated by the Indonesian Financial Service Authority OJK) influence on the Bank performance thus its competitiveness.

The importance of sustainable competitive advantages which is stated as company assets, attributes, or abilities that are difficult to duplicate or exceed; and provide a superior or favorable long term position over competitors (Faulkenberry, 2020) therefore, fits to the approach of Resource-based theory where it suggests that the resources possessed by a firm are the primary determinants of its performance, and this may contribute to the sustainable competitive advantage of the firm (Wernerfelt, 1984).

As Corporate governance mechanisms are categorized as firm's resources (Barney, 1991; 1996; 2001; Wernerfelt, 1984), Resource-Based View (RBV) is used as a basis for sustainable competitive advantage of a firm that consists of valuable, tangible and/or intangible resources at the firm's own used (Barney et al., 2001; Barney, 1991).

Therefore, as $\mathrm{BoC}$ is one of the important corporate governance mechanisms (Baysinger \& Butler, 1985) its role is critical in determining the achievement of sustainable competitive advantage of the firm through corporate governance.
Wernerfelt (1984), cited that resource-based theory underlines the role of independent commissioners which is supposedly to bring the unique resources to the firm and it is the task of the management team to gather and deploy the unique assets of the independent commissioners to achieve the competitive advantage goal of the firm. Barney (1991) further contributes on the research and suggested that heterogeneity of firm's various resources determined the firm's sustainable competitive advantage. In an ever-changing environment, it is imperative for organization to continuously acquire, develop and upgrade its resources and capabilities to maintain competitiveness and growth (Wernerfelt, 1984).

In this paper, resource-based theory will be applied in the perspective of strategic role of $\mathrm{BoC}$ as corporate governance mechanisms in mitigating Agency Dynamics in Agency Theory towards and achieving the Bank's sustainable competitiveness. The study is based on the assumption that Banks are involved in greater information asymmetries and complexity of business transactions are at a higher level when compared with non-Banks (Andres \& Vallelado, 2008). Business complexities can be in the form of loans quality that are not being clearly perceived, non-transparent financial engineering, complicated financial statements, easily modified investment risk, or accessibility of perquisites information for managers or insiders.

\section{LITERATURE REVIEW AND HYPOTHESIS DEVELOPMENT}

\section{Agency Theory}

Agency theory is the cornerstone of corporate governance research (Bosse \& Phillips, 2016). Much of the research on corporate governance derives from agency theory (Chidziva, 2016). Agency theory originated from Adam Smith's Wealth of Nations. In 1976, Jensen (2000) developed the agency theory (Al Mamun et al., 2013). When a firm is controlled by some people other than the owners the objectives of the owners are likely to be subordinated to the objectives of the managers (Alalade, Onadeko, \& Okezie, 2015; Al Mamun et al., 2013). Berle and Means (1932) argued that there was a need for mechanisms to monitor the managers (Al Mamun et al., 2013).

The foundation of agency theory hinges on the belief that the interests of the principals and the managers differ (Dawar, 2014). Because shareholders entrust corporate managers to manage the firm's assets, a potential conflict of interest exists between the two groups (Chidziva, 2016). Corporate managers may have personal goals that conflict with the long-term shareholders' objective of wealth maximization. The agent will not always act in the interest of the principal (Jensen, 2000). Agency theorists assume that the potential conflict of interest between corporate managers and owners will result in poor firm performance because corporate managers may use their control to advance their personal interests to the prejudice of 
the firm (Jensen, 2000).

El-Chaarani (2014) suggested that to lessen agency conflict; corporate governance presents directions and rules to align diverse interests, largely managers' interests, with those of the shareholders.

A $\mathrm{BoC}$ is a critical corporate governance mechanism set up to help mitigate conflicts of interests by monitoring activities of corporate managers (Ali \& Nasir, 2014). Agency theorists contend that the primary responsibility of the board of directors is towards the shareholders to ensure maximization of shareholder value (Chidziva, 2016). Boards of Commissioners control and monitor the top management of firms on behalf of the shareholders (Kilic, 2015; Jan, \& Sangmi, 2016). The responsibilities of the board include providing strategic direction to the firm (Nekhili \& Gatfaoui, 2013), determination of compensation packages for corporate managers, evaluation of managers' performance (Wang \& Hsu, 2013), and enhancements of internal control systems (Lambe, 2014; Mangena \& Vutete, 2015). The BoC of a company provides strategic guidance and leadership, objective judgment, independent of management, to the company and exercises control over the company, while at all times remaining accountable to the shareholders (Chatterjee, 2011).

\section{Corporate Governance and Bank Failures}

It is generally believed that corporate governance improves firms' financial performance (Attia, 2012; Rahman, Ibrahim \& Ahmad, 2015). Poor corporate governance is stated to be one of the main causes of financial crises (Htay, 2012). Weak implementation of corporate governance leads to firms' poor financial performance which ultimately leads to corporate failure (Norwani, Mohamad, \& Chek, 2011). Sound corporate governance policies are important to the creation of shareholders value and maintaining the confidence of customers and investors alike (Sangmi \& Jan, 2014).

Corporate governance has emerged as an important tool to curb Banking fraud, and there is need to evaluate the level of enforcement of corporate governance practices (Tabassum, 2015). Poor corporate governance of the Banks can drive the market to lose confidence in the ability of a Bank to properly manage its assets and liabilities (Htay, 2012).

Mamta (2015) reviewed some of the governance mechanisms and their adequacy in protecting shareholder interest and established that corporate governance provides shareholders with a range of mechanisms to check managerial greed, opportunism and earnings manipulation. Deb (2013) conducted a study among senior managers of public and private sector Banks in India to determine their corporate governance practices. A comparative study across the Banks revealed that public Banks were more transparent in comparison to private
Banks. Corporate governance has fast emerged as a benchmark for judging corporate excellence in the context of national and international business practices (Deb, 2013).

Oghojafor et al. (2010) investigated the extent to which non-compliance with corporate governance codes by Bank executives contributed to the Banking crisis, to ascertain the extent of the regulatory authority's complicity and laxity in the Banking crisis and to extend possible solutions to resolve the crisis and prevent future reoccurrence. Oghojafor et al. (2010) confirmed that poor governance culture and supervisory laxities were largely responsible for the Nigerian Banking crisis. The regulatory authorities should have the capacity and will to enforce sound corporate governance.

Javed, Saeed, Lodhi, \& Malik (2013) investigated the role of the board in firm performance in the Banking sector of Pakistan and concluded that there was a positive relationship between the number of directors, non-executive directors, female directors, CEO duality, and firm performance. Vo \& Phan (2013) established that female board members and CEO duality have positive effects on the performance of firms. Adekunle \& Aghedo (2014) investigated the relationship between corporate governance variables namely board composition, board size, and CEO status and ownership concentration and concluded that there was a positive and significant relationship between CEO status, board composition and board size and firm performance. Akbar (2015) investigated the relationship between corporate governance and firm performance using corporate governance constructs such as ownership concentration, board size, board composition, and the dual role of CEO and chairperson of board of directors and concluded that corporate governance positively and significantly contributed towards firm performance. Akbar (2014) examined the relationship between ownership concentration, board size, CEO duality and firm performance in the textile industry in Pakistan and found a significant positive relationship between small board size and return on assets.

Tai (2015) investigated the impact of corporate governance on the efficiency and financial performance of the GCC Banking sector and found that board size was a significant factor affecting financial performance.

Li, Armstrong, \& Clarke (2014) argued that Islamic Banks performed better if there was a higher proportion of independent directors on the board, numerous Commissioners, the CEO was chairperson, auditing was enforced, and ownership structure was dispersed.

Shukeri, Shin, \& Shaari (2012) investigated the effect of board size and ethnic diversity on firm performance and concluded that board size had a positive relationship with 
return on equity while board independence had a negative relationship. Hoque, Islam, \& Ahmed (2014) investigated the influence of corporate governance mechanisms on the financial performance of 25 listed Banks in Bangladesh during the period 2003-2011 and found that independent commissioners had a significant positive effect on Bank performance.

\section{A Resource-Based View Corporate Governance}

The Resource-Based View (RBV) sees the firm as a bundle of tangible and intangible resources (Penrose, 1959; and Wernerfelt, 1984). The RBV of the firm (Barney, 1986, 1991, 1995; Peteraf, 1993; Rumelt, 1982; Wernerfelt, 1984) suggests that a source of sustainable competitive advantage lies in the uniqueness of firm resources and capabilities.

A firm's resources can be the basis of sustained competitive advantage if the resources are valuable, rare, imperfectly imitable, and not substitutable (Barney, 1991).and therefore, RBV posits that one source of competitive advantage is private information that may be impounded by firm management constraining competitors from accessing the same information (Barney, 1995).

Pearlson \& Saunders (2013) stated in the relation of RBV with information access is in determining whether a firm's strategy has created value by using IT. This view maintains that competitive advantage comes from the information and other resources of the firm.

The requirement of RBV for 'valuable, rare, inimitable and non-substitutable' resources could also be applied to the unique combination of resources within the $\mathrm{BoC}$ of the firm. A Board's characteristics, such as its members' knowledge and experience, are much harder for competitors to imitate than to imitate other aspects of board composition such as size or the ratio of executive/outside board members. These are easier to imitate and therefore less significant for creating a sustainable competitive advantage. RBV theory is linked to board characteristics in terms of idiosyncratic resources that may prove to be sources of competitive advantage to firms as it underlines the role that the $\mathrm{BoC}$ can play in bringing unique resources to the firm. (Madhani, 2017).

Independent Commissioners often are also members of the corporate community and experience similar competitive, technological, and regulatory contexts (Baysinger \& Hoskisson, 1990) as the top managers on whose boards they serve. Baysinger \& Hoskisson (1990) further stated that if the experiences that commissioners bring to the firm are strategically relevant to the firm's top management, the experience, knowledge, and expertise of commissioners may become integrated (through the similarity of outside commissioners' experience to the firm's strategies) with firm internal resources and processes contributing to the firm's ability to impound information and the asset specificity and indivisibility of its knowledge base. Hence, Baysinger \&
Hoskisson (1990) stated that commissioners' experience, knowledge, and expertise may be considered firm resources, and the RBV may be used to investigate whether boards enhance firm governance in a way that makes the board a source of firm competitive advantage.

RBV emphasizes governance structure and the board composition as a resource that can add value to the firm. GarciaMeca and Palacio (2018) in their study about the influence of board experience, skills and expertise on firm reputation of companies in Spain provides empirical evidence to support the idea that board composition in relation to experience, background and connections has an important influence on stakeholders' perceptions and hence on firm reputation. The results support the view that firms should highlight the unique monitoring and advisory capabilities of directors and note that distinguishing directors according to their skills and abilities is crucial to understanding how boards impact on reputation.

The BoC might be seen as a valuable resource of the firm when it is actively involved in strategic decision making. Effective involvement in the process requires skills and the board's in-depth knowledge (Stiles, 2001; and Ruigrok et al., 2006). Board knowledge reflects the degree of BoC' understanding of firm operations and includes profound knowledge of the firm's industry, competitors, customers, technology, etc. Board members provide different perspectives and experiences from other firms and industries. Outside Commissioners have greater breadth of knowledge and experience from external sources than insiders (Wagner et al., 1998). Under RBV, the board would be seen as a unique, tacit (i.e., invisible), socially complex (i.e., based on team effort), and internal resource which can help a firm to enhance performance (Hart, 1995).

According to the RBV of the firm, Commissioners' indepth knowledge and diverse expertise represent a source of competitive advantage, which can lead to superior board performance. This diverse expertise includes scarce resources such as business and financial sector knowledge (Kakabadse et al., 2001), strategic expertise (Zahra \& Pearce, 1989; and Golden \& Zajac, 2001), and better governance (Khanna \& Palepu, 2004).

\section{Research Hypothesis}

Commissioners' experience, knowledge, expertise and other attributes may be considered firm resources (Weisbach, 1988; Rosentein \& Wyatt, 1990; Brickley et al., 1994), and RBV approach may be used to investigate whether boards enhance firm governance in a way that makes the board a source of firm competitive advantage (Madhani, 2017) and this leads to the following hypothesis:

H1 : Commissioners' Attributes positively affect Board of Commissioner (BoC) performance in RBV approach. 
Several aspects of the board may be considered: board structure (Adekunle \& Aghedo, 2014) and board independence (Syed Fuzi et al, 2016), functions of the board and the activities of board committees, access to information and general support for independent directors, and director compensation and liability (Nam, 2004). Therefore, the next hypothesis:

H2 : Board's Attributes positively affect BoC performance in $R B V$ approach.

Information access and Disclosure such as external audit provides information to $\mathrm{BoC}$ on threats and opportunities in the business environment that could impact your strategic decisions on issues such as new product development, market entry or exit, mergers and acquisitions, and resource allocation (Linton, 2019) and also the ability of BoC to perform its oversight role is, to a large extent, dependent upon the relationship and the flow of information from the company and high-quality, timely and credible information provides the foundation for effective responses and decision-making by the BoC (Lipton et al., 2018) and therefore the next hypothesis will be tested:

H3 : Access for Information and Disclosure positively affect BoC performance in RBV approach.

Pearlson \& Saunders (2013) stated in the relation of RBV with information access that competitive advantage comes from the information and other resources of the firm and therefore the following hypothesis will be tested:

H4: Access for Information and Disclosure positively affect Sustainable Competitive Advantage of the Bank.

The Resource-Based View (RBV) of the firm (Barney, 1986, 1991, 1995; Peteraf, 1993; Rumelt, 1982; Wernerfelt, 1984) suggests that a source of sustainable competitive advantage lies in the uniqueness of firm resources and capabilities. The concepts of the Resource-Based View of the firm may also be applied to parts of the firm such as the $\mathrm{BoC}$ and therefore the next hypothesis is:

H5 : BoC performance in RBV approach positively affect Sustainable Competitive Advantage of the Bank.

The existence of boards of commissioners who are competent and independent is expected to be able to better monitor and provide more valuable input in solving agency problems between owners and managers (Fama and Jensen, 1983; Shleifer and Vishny, 1997).

Therefore, a sound understanding of the Board's strategic role within the dynamics of Agency Theory and agency problem in the Corporate Governance perspective is important (Nicholson \& Kiel, 2004; dan Bonn \& Pettigrew, 2009) in preliminary identification of the potential areas to be supervised and mitigated and this study proposes the following hypothesis:

H6 : BoC performance in RBV approach positively affect Bank's Agency dynamics and mitigation.

The agency problems that arise from the separation of ownership and control raises the need for a corporate governance framework which strengthens managerial accountability and encourages managers to maximize profits, rather than pursue their own objectives (Maher \& Andresson, 1999). The different interest might subsequently negatively affect the firm performance and competitiveness and therefore this will be tested in the following hypothesis:

H7: Agency Dynamics affect the Bank's Sustainable Competitive Advantage.

As stated in the background of $\mathrm{H} 1$ earlier where Commissioners' experience, knowledge, expertise and other attributes may be considered as firm resources, the role of $\mathrm{BoC}$ performance in RBV approach as mediating variable towards sustainable competitive advantage leads to the following hypothesis:

H8 : Commissioners' Attributes positively affect Bank's Sustainable Competitive Advantage through BoC performance in RBV approach.

Functions of the board and activities of board committees as Board's Attributes as part of Hypothesis 5 may be considered as firm resources and therefore the role of $\mathrm{BoC}$ in $\mathrm{RBV}$ as mediating variable towards sustainable competitive advantage leads to the following hypothesis:

H9 : Board's Attributes positively affect Bank's Sustainable Competitive Advantage through BoC performance in $R B V$ approach.

\section{RESEARCH METHODOLOGY}

\section{Research Design}

The research employs quantitative research methodology with a process of hypothesis testing, which is intended to identify and describe the nature of the relationship between certain variables, or to test the significance level of the relationship between two or more variables (Cooper \& Schindler, 2014). In this study, hypothesis testing was conducted to examine the effect of variables namely, Commissioners attributes, BoC attributes and Information Access and Disclosure towards the BoC performance in RBV and Agency Dynamics and their implication to the Bank's Sustainable Competitive Advantage.

\section{Population and Sample}

The object of analysis in this study are BoC members of national commercial Banks in Indonesia. There are a total 
of 115 Banks which divided into 4 categories based on the core equity and due to different characteristics among others in ownership structure, equity provision, and locally oriented business approach, this study will not include Regional Development Bank (BPD), Rural Banks (BPR), Foreign Bank and Banks in category 4 (which has core equity of $\mathrm{Rp} 30$ Trillion and above). Mainly due to the intense competition in the Bank category 1 to 3 (Dharma, 2019; Kristiyana 2019) which in total represent $40.8 \%$ of the total Banking Asset in Indonesia and the remaining $51.03 \%$ belongs to 5 Banks in category 4 (Franedya, 2019), BoC members will be limited from Banks in category 1 to 3 with equity up to 30 trillion rupiah and under this category, total number of Banks are 51 Banks.

In this study, the respondents to be taken from each Banks are: (1). Chairman; (2). Independent Commissioners; (3). Non-Independent Commissioners; Therefore, each Bank will be subjected to 4 samples, 51 x $4=204$ respondents. This study can be further elaborated that in taking the research sample, each Bank will be subjected to 4 respondents which is multiplied by as many as 51 national commercial Banks in Indonesia.

\section{Data collection techniques}

In this study, data is collected and obtained by distributing questionnaires and approaching each target unit directly in the Bank in accordance with the prescribed research sample. After allowing certain period to fill out the questionnaire, it will be re-confirmed to the respondent that the collected data will be used as primary data by the researcher.

The data measurement technique is Likert scale, a scale used to measure attitudes, opinions, and perceptions of a person or group of people on an event, where the measured variable is described as an indicator, the indicator will then be used as a starting point for preparing statement items. Assessment for each question is measured by levels 1 to 5 categories, namely: 1. Strongly Disagree, 2. Disagree, 3. Neutral 4. Agree, and 5. Strongly agree.

\section{Data Analysis Method}

The study data analysis method will employ SmartPLS 2.0 program. PLS (Partial Least Square) is a variance-based structural equation analysis (SEM) that can simultaneously execute measurement model testing and structural model testing. The measurement model is used to test the validity and reliability, while the structural model is used to test causality (hypothesis testing with predictive models).

The employment of PLS data analysis is suitable to the current study as Ghozali (2011) mentioned that PLS is a soft modeling analysis method as it does not assume the data must be within a certain scale measurement, which means it can accommodate small number of samples (less than 100 samples) as the current study obtained.

\section{RESEARCH OUTCOME AND DISCUSSION \\ Respondent's Profiles}

From 97 respondents, 42 respondents ages from 51 to 55 which represent $43.3 \%$ respondents and smaller portion of respondents ( 2 respondents) ages from 26 to 30 which represent $2.1 \%$ respondents. Based on sex it is known that there are more male than female respondents, namely 72 male or $74.2 \%$ and 25 female or $25.8 \%$. Based on educational level it is known that most of the respondents are in the Sarjana (Bachelor) Degree, which is 52 or $53.6 \%$ respondents and the least respondent is in the Doctoral Degree (S3), which is 2 person or $2.1 \%$ of respondents.

Structural Model (Inner Models) and Measurement Model (Outer Models)

A full SEM model testing parameter $\lambda$ (loading factor / coefficient indicator) measurements on exogenous and endogenous models was conducted where this test is intended to determine the strength of the indicators of each latent variable (construct).

For confirming a measurement model Hair et al. (2014) suggest the essentiality of Construct validity in confirming a measurement model. Every indicator that is declared valid

Table 1: Results of Validity and Reliability Tests

\begin{tabular}{|c|c|c|c|}
\hline Variable & AVE & $\begin{array}{c}\text { Composite } \\
\text { Reliability }\end{array}$ & $\begin{array}{c}\text { Cronbach's } \\
\text { Alpha }\end{array}$ \\
\hline Board Member Attributes & 0.673 & 0.961 & 0.956 \\
\hline Board's Attributes & 0.679 & 0.962 & 0.956 \\
\hline Information Access and Disclosure & 0.792 & 0.950 & 0.934 \\
\hline BoC performance in RBV approach & 0.768 & 0.968 & 0.962 \\
\hline Agency Dynamics & 0.592 & 0.929 & 0.916 \\
\hline Sustainable Competitive Advantage & 0.715 & 0.968 & 0.964 \\
\hline
\end{tabular}


and passes the test must meet the higher Loading Factor requirements of 0.5 (Hair et al., 2014). As for reliability, Average Variance Extracted (AVE) values are higher than 0.5, Composite Reliability and Cronbach's Alpha values are higher than 0.7 .

Notes: All constructs using five-point Likert scale, from 1 "Strongly disagree" to 5 "Strongly agree". The validity and reliability test above showed that indicators in this study has an acceptable level of validity and reliability, where all indicators have loading factor (not shown) and AVE value $\geq$ 0.50 and each construct has Cronbach's alpha $\geq 0.70$.

Next, results obtained from SmartPLS 2.0 calculation contained information of estimate calculation of structural equations or equations of inner models. This correlates to the evaluation of coefficients or parameters that show the causal relationship or the effect of one latent variable to other latent variables.

After confirmatory factor analysis above, the next step is to test the significance of the estimated parameters. In this case, evaluating the significance of the estimated parameters is done by comparing the value of $t$ value with the critical value (table value at $95 \%$ confidence level or $\mathrm{a}=5 \%$ with a $\mathrm{t}$-value \pm 1.96 ). The results of this evaluation can be summarized in the table below which is accompanied by hypotheses testing of the following research model:

\section{Discussion}

The PLS calculation as shown in table 2 and further summarized in figure 1 has shown that in the structural model, Board Member Attributes, Board's Attributes, and Information Access and Disclosure positively and significantly affect the endogenous variables BoC performance in RBV approach where the most dominant exogenous variable to affect the endogenous variable is the Board Member Attributes with Beta value of 0.333 and the Information Access and Disclosure is the least dominant exogenous variable with Beta value of 0.277 .

Through BoC performance in RBV approach as the mediating variable, it can be observed that Board Member Attributes has the most dominant indirect effect to the endogenous variable Sustainable Competitive Advantage with Beta value of 0.196 while on the contrary, Board Attributes has the least dominant indirect effect to the endogenous variable Sustainable Competitive Advantage with Beta value of 0.185 .

The results obtained using the SmartPLS 2.0 program for the proposed hypothesis can be seen in table 2, with the following details:

Board Member Attributes directly affect BoC performance in Resource-Based View approach significantly with t-value of 2.279 (t-value $>1.96$ ) which means hypothesis $\mathrm{H} 1$ is accepted

Table 2: Results of Hypothesis Tests

\begin{tabular}{|c|c|c|c|}
\hline Path & Beta & t-value & Result \\
\hline $\begin{array}{c}\text { Board Member Attributes } \rightarrow \text { BoC performance } \\
\text { in RBV approach }\end{array}$ & 0.333 & 2.279 & Accepted \\
\hline Board's Attributes $\rightarrow$ BoC performance in RBV approach & 0.313 & 2.313 & Accepted \\
\hline $\begin{array}{c}\text { Information Access and Disclosure } \rightarrow \text { BoC performance } \\
\text { in RBV approach }\end{array}$ & 0.277 & 4.010 & Accepted \\
\hline $\begin{array}{c}\text { Information Access and Disclosure } \rightarrow \text { Sustainable } \\
\text { Competitive Advantage }\end{array}$ & 0.332 & 3.279 & Accepted \\
\hline $\begin{array}{c}\text { BoC performance in RBV approach } \rightarrow \text { Sustainable } \\
\text { Competitive Advantage }\end{array}$ & 0.590 & 5.589 & Accepted \\
\hline BoC performance in RBV approach $\rightarrow$ Agency Dynamics & 0.349 & 3.032 & Accepted \\
\hline Agency Dynamics $\rightarrow$ Sustainable Competitive Advantage & -0.086 & 1.075 & Rejected \\
\hline $\begin{array}{l}\text { Board Member Attributes } \rightarrow \text { BoC performance in RBV approach } \rightarrow \text { Sustain- } \\
\text { able Competitive Advantage }\end{array}$ & 0.196 & 2.110 & Accepted \\
\hline $\begin{array}{c}\text { Board's Attributes } \rightarrow \text { BoC performance in RBV approach } \rightarrow \text { Sustainable } \\
\text { Competitive Advantage }\end{array}$ & 0.185 & 2.137 & Accepted \\
\hline
\end{tabular}




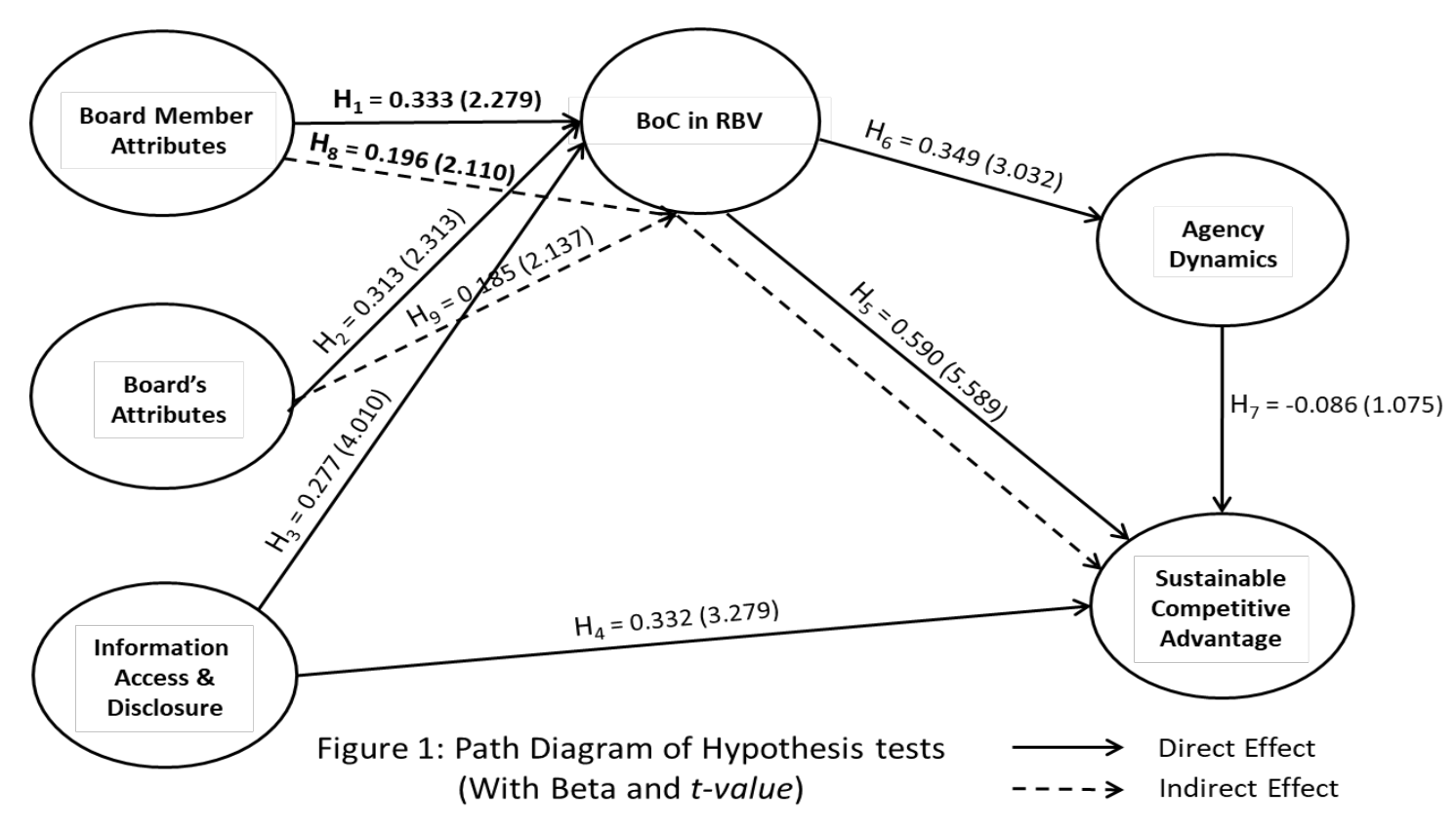

and Beta value or the effect of Board Member Attributes on $B o C$ performance in $R B V$ approach is 0.333 . This means a better Board Member Attributes will result a better BoC performance in $R B V$ approach. This further means that more respondents perceive that independent commissioner must be free from personal, financial and social influence or relationship with the Board of Directors / management to be able to provide an objective perspective in providing analysis and advice in its function in the Board of Commissioners, the more respondents perceive that expertise, experience and extensive knowledge, and competence of the Board of Commissioners' risk management are special resources that significantly help formulate the Bank's strategy and other important decisions.

Board's Attributes directly affect BoC performance in $R B V$ approach significantly with t-value of 2.313 (t-value $>1.96$ ) which means hypothesis $\mathrm{H} 2$ is accepted and Beta value or the effect of Board's Attributes on BoC performance in RBV approach is 0.313 . This means a better Board's Attributes will result a better $B o C$ performance in $R B V$ approach. This further means that more respondents perceive that Committees of the Board of Commissioners and their structures are important to support the effective role of the Board of Commissioners, the more respondents perceive that expertise, experience and extensive knowledge, and competence of the Board of Commissioners' risk management are special resources that significantly help formulate the Bank's strategy and other important decisions.

Information Access and Disclosure directly affect $B o C$ performance in RBV approach significantly with t-value of $4.010(\mathrm{t}$-value $>1.96)$ which means hypothesis $\mathrm{H}_{3}$ is accepted and Beta value or the effect of Information Access and Disclosure on BoC performance in RBV approach is 0.277 . This means a better Information Access and Disclosure will result a better BoC performance in $R B V$ approach. This further means that more respondents perceive that The Board of Commissioners needs to have full access to market analysis and banking industry information, the more respondents perceive that expertise, experience and extensive knowledge, and competence of the Board of Commissioners' risk management are special resources that significantly help formulate the Bank's strategy and other important decisions.

Information Access and Disclosure directly affect Sustainable Competitive Advantage of the Bank significantly with t-value of 3.279 (t-value $>1.96$ ) which means hypothesis $\mathrm{H}_{4}$ is accepted and Beta value or the effect of Information Access and Disclosure on Sustainable Competitive Advantage is 0.332. This means a better Information Access and Disclosure will result a better achievement of Sustainable Competitive Advantage. This further means that more respondents perceive that The Board of Commissioners needs to have full access to market analysis and banking industry information, the more respondents perceive that the Bank has implemented a focus strategy in particular markets to get customers.

$B o C$ performance in $R B V$ approach directly affect Sustainable Competitive Advantage significantly with t-value of 5.589 (t-value > 1.96) which means hypothesis $\mathrm{H}_{5}$ is accepted and Beta value or the effect of BoC performance in RBV approach on Sustainable Competitive Advantage is 0.590 . This means a better $B o C$ performance in $R B V$ approach 
will result a better mitigation to Agency Dynamics. This further means that more respondents perceive that expertise, experience and extensive knowledge, and competence of the Board of Commissioners' risk management are special resources that significantly help formulate the Bank's strategy and other important decisions, the more respondents perceive that the Bank has implemented a focus strategy in particular markets to get customers.

BoC performance in RBV approach directly affect Agency Dynamics significantly with t-value of 3.032 (t-value $>1.96$ ) which means hypothesis $H_{6}$ is accepted and Beta value or the effect of BoC performance in RBV approach on Agency Dynamics is 0.349 . This means a better BoC performance in RBV approach will result a better mitigation to Agency Dynamics. This further means that more respondents perceive that expertise, experience and extensive knowledge, and competence of the Board of Commissioners' risk management are special resources that significantly help formulate the Bank's strategy and other important decisions, the more respondents perceive that It is important to have a good oversight mechanism to enable the shareholders to avoid conflicts of personal interest from the Directors / management that can harm the Bank.

Agency Dynamics might not have direct effect on Sustainable Competitive Advantage and not significant with t-value of 1,075 (t-value $<1.96)$ which means hypothesis $\mathrm{H}_{7}$ is rejected and Beta value or the effect of Agency Dynamics on Sustainable Competitive Advantage is - 0.086 .

The total influence of Board Member Attributes on Sustainable Competitive Advantage through BoC performance in $R B V$ approach is 0.196 and the $\mathrm{t}$-value is 2.110 ( $\mathrm{t}$-value $>1.96$ ) which means hypothesis H8 is accepted. Therefore, the mediating influence of $B o C$ performance in $R B V$ approach to Board Member Attributes and Sustainable Competitive Advantage is positive and significant. This means a better $B o C$ performance in $R B V$ approach will increase the effect of Board Member Attributes on Sustainable Competitive Advantage. This further means that more respondents perceive that expertise, experience and extensive knowledge, and competence of the Board of Commissioners' risk management are special resources that significantly help formulate the Bank's strategy and other important decisions will increase the influence of independent commissioner must be free from personal, financial and social influence or relationship with the Board of Directors / management to be able to provide an objective perspective in providing analysis and advice in its function in the Board of Commissioners which will lead to the Bank has implemented a focus strategy in particular markets to get customers.

The total influence of Board's Attributes on Sustainable Competitive Advantage through BoC performance in $R B V$ approach is 0.185 and the t-value is 2.137 ( $\mathrm{t}$-value $>1.96$ ) which means hypothesis $\mathrm{H}_{9}$ is accepted. Therefore, the mediating influence of $B o C$ performance in $R B V$ approach to Board's Attributes and Sustainable Competitive Advantage is positive and significant.

This means a better $B o C$ performance in $R B V$ approach will increase the effect of Board's Attributes on Sustainable Competitive Advantage. This further means that more respondents perceive that Committees of the Board of Commissioners and their structures are important to support the effective role of the Board of Commissioners will increase the influence of independent commissioner must be free from personal, financial and social influence or relationship with the Board of Directors / management to be able to provide an objective perspective in providing analysis and advice in its function in the Board of Commissioners which will lead to the Bank has implemented a focus strategy in particular markets to get customers.

\section{CONCLUSION AND MANAGERIAL IMPLICATIONS}

Based on the study that was conducted to Chairman, Independent Commissioners and Commissioners from 51 national commercial Banks category 1 to 3 in Indonesia, in general, it can be concluded that from the results of hypothesis testing and discussion in the previous chapters, Board Member Attributes, Board's Attributes, and Information Access and Disclosure positively affect BoC performance in RBV approach with Board Member Attributes as the most dominant exogenous variable. Whereas Information Access and Disclosure and BoC performance in RBV approach affect the endogenous variable Sustainable Competitive Advantage. The study also reveals that Agency Dynamics has no significant effect to Bank's Sustainable Competitive Advantage.

Further analysis correspondingly shows that $\mathrm{BoC}$ in $\mathrm{RBV}$ approach is proven to mediate exogenous variables Board Member Attributes, Board's Attributes, and Information Access and Disclosure towards the Bank's Sustainable Competitive Advantage.

\section{Managerial Implications}

Based on empirical findings obtained in this research, the managerial implications of this research can be proposed for Indonesian Bank's relevant stakeholders to improve the quality and effectiveness of Board Member Attributes, Board's Attributes, Information Access and Disclosure, in optimizing the strategic role BoC performance in $\mathrm{RBV}$ approach, addressing and mitigating Agency Dynamics towards achieving the Bank's Sustainable Competitive Advantage. Based on findings and discussion of the research, the suggestions are as follows:

\section{Board Member Attributes}

As an exogenous variable with the strongest effect on BoC in the RBV approach, suggested actions within Board Member Attributes variable and competencies dimension are for bank owners and related parties (including Financial Service 
Authorities / OJK) to ensure that on the selection of $\mathrm{BoC}$ members, for the selected candidates to have competencies as stated in the variable's indicators. OJK also plays important role in the fit and proper test for ensuring the candidate to have the suggested required attributes. Executive training and refreshment for updates in the banking industry, financial regulation system, risk management, laws and regulations governing banking operations need to be carried out in periodically to maintain and improve existing Commissioners quality of competencies.

Board Member Attributes variable that need to be improved is the dimensions of Independence, where Bank owners need to ensure that the knowledge and expertise needed, such as strategic knowledge of multi-industry and sectors especially within the Bank's credit portfolio, are owned by selected candidates for Independent Commissioners.

\section{Board Attributes}

Suggested actions to be done within Board Attributes variable and Board Structure dimension are for bank owners and related parties to ensure the formation of $\mathrm{BoC}$ committee has fulfilled OJK regulation and if needed, to add more committee in supporting BoC role in its supervisory duty. The effectiveness of the committee also supported by competent committee members in their function as BoC mechanism in communicating and liaise with Bank's operational divisions especially in providing required data and information for the BoC.

Board Attributes variable that need to be improved is the dimensions of Board process, where $\mathrm{BoC}$ and related parties to ensure the Board to formally meet and discuss internally as well as with the Board of Executives in an agreed period to monitor Bank's performance and follow up actions.

\section{Information Access and Disclosure}

Suggested actions to be done within Information Access and Disclosure variable and Internal Information dimension are to ensure that Board of Executives and related Operational Division, to periodically submit the related performance reports and audit report through BoC Committee. The internal report will include actual against targeted performance and performance benchmark against other peer Banks within the same category or similar asset size.

Information Access and Disclosure variable that need to be improved is the dimension of External Information, where BoC and related parties to ensure that information transparencies and disclosures have been submitted by the management, either in the company's website as part of the investor relation, Corporate Social Responsibility (CSR), Corporate Governance Self-assessment and other reports that need to be periodically published whilst ensuring the accuracy and timeliness of those reports.

\section{BoC in RBV approach}

Suggested actions to be done within BoC in RBV approach variable and Providing expertise dimension are for bank owners and related parties to ensure that on the selection of BoC members, the selected candidates to have expertise, experience, track records and extensive knowledge in Banking Industry, and risk management competencies to enable formation of Board composite competencies, strengthened by Executive training and refreshment for updates in the banking industry, financial regulation system, risk management, laws and regulations governing banking operations.

BoC in RBV approach variable that need to be improved is the dimensions of Enhancing the legitimacy and public image, where $\mathrm{BoC}$ and related parties to ensure that connections and relations to certain political or institution must affect company's reputation and legitimacy positively and do their utmost to prevent such connection to be abusive.

\section{Agency Dynamics}

Suggested actions to be done within the Agency Dynamics variable and Personal goals dimension are for bank owners and related parties to ensure for the $\mathrm{BoC}$ as an important Corporate Governance mechanism to conduct its strategic function to optimally supervise and advise the management in running the operational activity supported by attributes and supporting structures mentioned in this research above.

Agency Dynamics variable that need to be improved is the dimensions of Asymmetry information, where BoC and related parties to ensure that $\mathrm{BoC}$ through its committee has full access to information especially to Bank's real performance and operation especially for activity such as (1) Loan provision to related party and certain values and client's profile; (2) Procurement process that require certain bidding mechanisms, to ensure that the process is conducted transparently and meeting targeted quality assurance.

\section{Sustainable Competitive Advantage}

Suggested actions to be done within the Sustainable Competitive Advantage variable and Focus dimension are for BoC and related parties to ensure that the Bank's selection of certain market segment has undergone detailed analysis whilst ensuring that the Bank has sufficient resources to effectively implement the selected market strategy. BoC need to closely supervise the strategy implementation process and provide necessary advice based on the implementation performance periodically report.

Sustainable Competitive Advantage variable that need to be improved is the dimensions of Differentiation, where $\mathrm{BoC}$ and related parties to ensure that the low-cost service and product strategy has undergone detailed analysis whilst ensuring that the Bank has sufficient resources to effectively implement the selected market strategy. BoC need to closely supervise the 
strategy implementation process and provide necessary advice based on the implementation performance periodically report.

\section{Research Limitation and Recommendations}

The writer, however, recognizes that this study has potential limitations, among others: The quantitative research method used in this study involves structured questionnaire with close ended questions. It leads to limited outcomes outlined in the research proposal. Therefore, the results might not always represent the actual occurring, in a generalized form. Furthermore, the respondents might have limited options of responses, based on the selection made by the researcher (Chetty, 2016); Current study is limited to study the relationship of six variables, namely: Board Member Attributes, Board's Attributes, Information Access and Disclosure, BoC performance in RBV approach, Agency Dynamics and Sustainable Competitive Advantage.

As the current study endeavors to investigate and analyze the indicators of attributes and other factors as perceived by the Board of Commissioners members to signifies their role as the Bank's resources to minimize agency cost in achieving sustainable competitive advantage, for further study the writer suggest to continue the current study by adding new indicators such as financial performance of the Banks and evaluate its major financial indicators as suggested by Peni, E., \& Vähämaa, S. (2011), Latif, Shahid, Haq, Waqas, \& Arshad (2013) such as Return on Equity (RoE), Return on assets (RoA), Net Income Margin (NIM), Operation Expenses to Operating Revenues ratio, Capital Adequacy Ratio (CAR) and loan quality as indicated by the Non-Performing Loan (NPL) percentages.

Other area of further study to be suggested is exploring the additional supervision if the bank is listed in the stock market (Peni, E., \& Vähämaa, S., 2011) such as The Capital Market and Financial Institution Supervisory Agency (abbreviated Bapepam-LK ) and OJK, and whether this factor will enable $\mathrm{BoC}$ to perform even better as the accountability to a more diverse shareholders and transparency will have positive effect on the performance.

BoC strategic role can be further analyzed by confirmation of the Board as company resources where it is expected that Agency Dynamics mitigation can be done more optimally as factors and variables in current study can be carried on by following study and confirmation from the further study financial indicators and Bank's other major indices (Syed Fuzi, S. F., Abdul Halim, S. A., \& Julizaerma, M. K., 2016).

\section{References}

1. Adekunle, S. M., \& Aghedo, E. M. (2014). Corporate governance and financial performance of selected quoted companies in Nigeria. European Journal of Business and Management, 6(9), 53-60. Retrieved from www. iiste.org

2. Akbar, A. (2014). Corporate governance and firm performance: Evidence from textile sector of Pakistan. Journal of Business Strategy, 4, 200-207. Retrieved from http://aressweb.com

3. Akbar, A. (2015). The role of corporate governance mechanism in optimizing firm performance: A conceptual model for corporate sector of Pakistan. Asian Economic and Social Society, 5(6), 109-115. Retrieved from www.aessweb.com

4. Al Mamun, A., Yasser, Q. R., Entebang, H., \& Nathan, T. M. (2013). Gender diversity and economic performance of firms: Evidences from emerging market. Journal of Economic Development, Management, IT, Finance and Marketing, 5, 100-110. Retrieved from http://www.researchgate.net

5. Alalade, Y. S. A., Onadeko, B.B., \& Okezie, O.F. (2015). Corporate governance practices and firms' financial performance of selected manufacturing companies in Lagos State, Nigeria. International Journal of Economics, Finance, and Management Sciences, 2, 285-296. doi:10.11648/j.ijefm.20140205.13.

6. Ali, A., \& Nasir, S. B. (2014). Impact of board characteristics and audit committee on financial performance: A study of manufacturing sector of Pakistan. Research Journal of Finance and Accounting, 5(7), 144-151. Retrieved from www.iitse.org

7. Andres, P. De, \& Vallelado, E. (2008). Corporate Governance in Banking: The Role of the board of Directors. Journal of Banking and Finance, 32(12), 2570-2580.

8. Attia, M. B. R. (2012). Accounting income smoothing, hedging and corporate governance. Global Business and Management Research: An International Journal, 4, 149-163. Retrieved from http://www.gbmr.ioksp. com

9. Barney, J. B. (1986). Strategic factor markets: Expectations, luck, and business strategy. Management Science, 32, 1231-1241.

10. Barney, J. B. (1991). Special Theory Forum The resource-based model of the firm. Journal of Management and Innovation, 4(1), 46-68.

11. Barney, J. B. (1995). Looking inside for competitive advantage. Academy of Management Executive, 9(4), 49-61.

12. Barney, J. B. (1996). The Resource-Based Theory of the Firm. Organization Science, 7(5), 469-469.

13. Barney, J. B. (2001). Is the Resource-Based "View" a Useful Perspective for Strategic Management Research? Yes. The Academy of Management Review, 26(1), 41.

14. Barney, J. B., \& Arikan, A. M. (2001). The Resource-Based View: Origins and implications. In Hitt, M. A., Freeman, R. E., \& Harrison, J. S. (eds.). Handbook of strategic management. Blackwell Publishers: Oxford, UK; 124-188.

15. Baysinger, B., \& Butler, H. N. (1985). Corporate governance and the board of directors: Performance effects of changes in board composition. Journal of Law, Economics, and Organization, 1, 101-124.

16. Baysinger, B., \& Hoskisson, R. E. (1990). The composition of board of directors and strategic control: Effects on corporate strategy. Academy of Management Review, 15, 72-87.

17. Berle, A. A. \& Means, G. C. (1932). The modern corporation and private property. New York, N.Y: Macmillan.

18. Bonn, I. \& Pettigrew, A., (2009). Towards a Dynamic Theory of Boards: An Organizational Life Cycle Approach. Journal of Management \& Organization, 15(1), 2-16.

19. Bosse, D. A., \& Phillips, R. A. (2016). Agency theory and bounded self interest. Academy of Management Review, 41, 276-297.doi:10.5465/ amr.2013.0420.

20. Brickley, J. A., Coles, J. L., \& Terry, R. L. (1994). Outside Directors and the Adoption of Poison Pills, Journal of Financial Economics, 35 (30), $371-390$.

21. Chatterjee, S. H. D. (2011). Board composition and performance in Indian firms: A comparative analysis empirical. The International Journal of Management Science and Information Technology (IJMSIT), 1(2), 1-15. 
Retrieved from http://www.naisit.org

22. Chetty, P. (2016). Limitations and weakness of quantitative research methods. Retrieved from https://www.projectguru.in/limitationsquantitative-research.

23. Chidziva, B. (2016). The Role of Corporate Governance in Preventing Bank Failures in Zimbabwe. : Walden University.

24. Cooper, D.R. and Schindler, P.S. (2014). Business Research Methods. New York: McGraw-Hill.

25. Dawar, V. (2014). Agency theory, capital structure, and firm performance: Some Indian evidence. Managerial Finance, 40 , 1190-1206. doi:10.1108/ MF-10-2013-0275.

26. Deb, R. (2013). Corporate Governance Practices in Indian Banks. Journal of Business Management \& Social Sciences Research, 2(5).

27. Dharma, S. (2019). Berlomba naik BUKU, persaingan makin ketat. Kontan.co.id. Retrieved from https://keuangan.kontan.co.id/news/ berlomba-naik-buku-persaingan-makin-ketat?page=all.

28. El Chaarani, H. (2014). The impact of corporate governance on the performance of Lebanese Banks. The International Journal of Business and Finance Research, 8(5), 35-46. Retrieved from http://papers.ssrn.com

29. Fama, E., \& Jensen, M. C.(1983). Separation of ownership and control. Journal of law and Economics, 26, 301-325. Retrieved from http://www. jstor.org

30. Faulkenberry, K. (2020). Sustainable Competitive Advantages: Definition, Types, \& Examples. Retrieved from https://www.arborinvestmentplanner. com/ sustainable-competitive-advantages-definition-types-examples/

31. Franedya, R. (2019). Ada 115, Jumlah Bank di RI Terlalu Banyak. CNBC Indonesia. Retrieved from https://www.cnbcindonesia.com/ market/20190304072306-17-58632/ada-115-jumlah-bank-di-ri-terlalubanyak

32. Garcia-Meca, E., \& Palacio, C.J. (2018). Board composition and firm reputation: The role of business experts, support specialists and community influential. Business Research Quarterly, 21, 111-123.

33. Ghozali, I. (2011). Structural Equation Modeling Metode Alternatif Dengan Partial Least Square (PLS) Edisi 3, Semarang: Badan Penerbit UniversitasDiponegoro.

34. Golden, B. R., \& Zajac, E. J., (2001). When will Boards Influence Strategy? Inclination $\times$ Power $=$ Strategic Change. Strategic Management Journal, 22(12), 1087-1111.

35. Hair, J. F., Black, W. C., Babin, B. J., \& Anderson, R. E. (2014). Multivariate Data Analysis, 7th Edition. New International Edition., Essex: Pearson.

36. Hamada, M (2018). Impact of Foreign Bank Entry on SME Credit in the Indonesian Banking Sector. Journal of Southeast Asian Economies, suppl. Special Issue: Commemorating the 50th Anniversary of the ISEAS - Yusof Ishak Institute; Singapore, 35(1) (Apr 2018): 50-78. DOI:10.1355/ ae35-1f.

37. Harrison, J. R., (1987). The Strategic Use of Corporate Board Committees. California Management Review, 30(1), 109-125.

38. Hart, S. L. (1995). A Natural Resource Based View of the Firm. Academy of Management Review, 20(4), 986-1014.

39. Hillman, A. J., \& Dalziel, T. (2003). Boards of Directors and Firm Performance: Integrating Agency and Resource Dependence Perspectives. Academy of Management Review, 28(3), 383-396.

40. Hoque, Z. M, Islam, R., \& Ahmed H. (2014). Corporate governance and Bank performance: The case of Bangladesh. Retrieved from www.ssrn. com

41. Htay, S. N. N. (2012). The impact of corporate governance on the voluntary accounting information disclosure in Malaysian Listed Banks. Global Review of Accounting and Finance, 3, 128-142. Retrieved from https://www.researchgate.net
42. James, B. J., \& Joseph, C. (2015). Corporate Governance Mechanisms and Bank Performance: Resource-based View. Procedia Economics and Finance (31), $117-123$.

43. Jan, S., \& Sangmi, M. (2016). The role board of directors in corporate governance. Imperial Journal of Interdisciplinary Research, 2, 707-715. Retrieved from www.onlinejournal.in

44. Javed, M., Saeed, R., Lodhi, R. N., \& Malik, Q. U. Z. (2013). The effect of board size and structure on firm financial performance: A case of Banking sector in Pakistan. Middle East Journal of Scientific Research, 15 (2), 243251.doi:10.5829/idosi.mejsr.2013.15.2.11048.

45. Jensen, M. C. (2000). A Theory of the Firm: Governance,Residual Claims and Organizational Forms. Harvard University Press

46. Johnson, R. A., Hoskisson, R. E. \& Hitt, M. A. (1993). Board of Director Involvement in Restructuring: The Effects of Board Versus Managerial Controls and Characteristics. Strategic Management Journal, 14(S1), 3350 .

47. Johnson, J. L., Daily, C. M. \& Ellstrand, A. E., (1996). Boards of Directors: A Review and Research Agenda. Journal of Management, 22(3), 409-438.

48. Kakabadse, A., Ward, K., Korac-Kakabadse, N. \& Bowman, C. (2001). Role and Contribution of Non-Executive Directors. Corporate Governance: The International Journal of Business in Society, 1(1), 4-8.

49. Khanna, T. \& Palepu, K. (2004). Globalization and Convergence in Corporate Governance: Evidence from Infosys and the Indian Software Industry. Journal of International Business Studies, 35(6), 484-507.

50. Kilic, M. (2015). The effect of board diversity on the performance of Banks: Evidence from Turkey. International Journal of Business and Management, 10(9), 182-192.doi:10.5539/ijbm.v10n9p182.

51. Kristiyana, H. (2019). Ada 115, Jumlah Bank di RI Terlalu Banyak. CNBC Indonesia. Retrieved from https://www.cnbcindonesia.com/ market/20190304072306-17-58632/ada-115-jumlah-bank-di-ri-terlalubanyak

52. Lambe, I. (2014). Corporate governance and organizational performance in the Nigerian Banking industry. European Journal of Business and Management, 6(25),110-118. Retrieved from www.iiste.org

53. Latif, B., Shahid, M. N., Haq, M. Z. U, Waqas, H. M., \& Arshad, A. (2013). Impact of corporate governance on firm performance: Evidence from sugar mills of Pakistan. European Journal of Business and Management, 5(1), 9-16. Retrieved from www.iiste.org

54. Li, Y., Armstrong, A., \& Clarke, A. (2014). Relationships of corporate governance mechanisms and financial performance in Islamic Banks: A meta-analysis. Journal of Business Systems, Governance, and Ethics, 9(1). Retrieved from www.eds.b.ebsohost.com

55. Linton, I. (2019). How Does the External Audit Affect Other Components of the Strategic Management Process?. Available at: https://smallbusiness. chron.com/external-audit-affect-other-components-strategicmanagementprocess-33621.html

56. Lipton, M., Niles, S. V., Miller, M. L. (2018). Risk Management and the Board of Directors. Harvard Law School Forum on Corporate Governance. Available at: https://corpgov.law.harvard.edu/2018/03/20/ risk-management-and-the-board-of-directors-5/

57. Lutfi, Iramani, R. \& Silvy, M. (2012). The Role of Board of Commissioners and Transparency in Improving Bank Operational Efficiency and Profitability. Available at: https://www.academia.edu/8262625/ The Role_of_Board_of_Commissioners_and_Transparency_in_Improving_Bank_Operational_Efficiency_and_Profitability_Dec_3

58. Madhani, P. M. (2007). Corporate Governance from Compliance to Competitive Advantage, The Accounting World, 7(8), 26-31.

59. Madhani, P. M. (2009). Corporate Governance: A Journey from Compliance to Competitive Advantage. Available at: https://www. researchgate.net/publication/45072542_Corporate_Governance_A Journey_from_Compliance_to_Competitive_Advantage 
60. Madhani, P. M. (2014). Corporate Governance and Disclosure Practices of Indian Firms: An Industry Perspective. The IUP Journal of Corporate Governance, 13(2), 27-41.

61. Madhani, P. M. (2017). Diverse Roles of Corporate Board: A Review of Various Corporate Governance Theories. The IUP Journal of Corporate Governance, 16(2), 9-28

62. Maher, M. \& Andresson, T. (1999). Corporate Governance: Effects on firm performance and economic growth. Organisation for Economic CoOperation and Development.

63. Mamta, B. (2015). Corporate Governance of Public Sector Enterprise. Lap Lambert Academic Publishing GmbH KG.

64. Mangena, E., \& Vutete, C. (2015). Corporate governance performance of Zimbabwean state universities as a basis of quality higher education: The student and lecturer perspective. IOSR Journal of Business and Management, 17(6), 109-116. doi: 10.9790/487X-1762109116.

65. McNulty, T., \& Pettigrew, A., (1996). The Contribution, Power, and Influence of Part-Time Board Members. Corporate Governance: An International Review, 4(3), 160-179.

66. Nam, S. W., (2004). Relationship Banking and Its Role in Corporate Governance. Research Paper no.56. ADB Institute, Tokyo.

67. Nekhili, M., \& Gatfaoui, H. (2013). Are demographic attributes and firm characteristics drivers of genderdiversity? Investigating women's positions on French board of directors. Journal of Business Ethics, 118, 227-249, doi:10.1007/s10551-012-1576-z

68. Nicholson, G. J. \& Kiel, G. C. (2004). A Framework for Diagnosing Board Effectiveness. Corporate Governance: An International Review, 12(4), $442-460$.

69. Norwani, N. M., Mohamad, Z. Z., \& Chek, I. T. (2011). Corporate governance failure and its impact on financial reporting within selected companies. International Journal of Business and Social Science, 2(21), 205-213. Retrieved from http://www.ijbssnet.com.

70. Oghojafor B.E., Olayemi, O. and Okonji, S. (2010). Poor Corporate Governance and its Consequences on the Nigerian Banking Sector, Serbian Journal of Management, 5(2), 243- 250.

71. Oxfordbusinessgroupcom. (2017). Oxford Business Group. Retrieved 23 October, 2018, from https://oxfordbusinessgroup.com/indonesia-2018/ banking

72. Pearlson, K. E \& Saunders, C. S., (2013). Strategic Management of Information Systems. Singapore: John Wiley \& Sons.

73. Peni, E., \& Vähämaa, S. (2011). Did Good Corporate Governance Improve Bank Performance during the Financial Crisis? Journal of Financial Services Research; 41(1-2), (Apr 2012): 19-35. DOI:10.1007/s10693011-0108-9.

74. Penrose, E. T. (1959). The theory of the growth of the firm. New York: Wiley.

75. Peteraf, M. A. (1993). The cornerstones of competitive advantage: A Resource-Based View. Strategic Management Journal, 14, 179-191.

76. Rahman, A. A. (2006). Effective Corporate Governance. UiTM Press.

77. Rahman, H. U., Ibrahim, M. Y., \& Ahmad, A. C. (2015). Corporate governance, firm financial performance, and shareholder's confidence: A proposed analysis of MCCG 2012. Global Business and Management Research: An International Journal, 7(1), 139-147. Retrieved http://www. gbmr.ioksp.com
78. Rosenstein, S. \& Wyatt, J. G. (1990). Outside Directors, Board Independence, and Shareholder Wealth, Journal of Financial Economics, 26, 175-184.

79. Ruigrok, W., Peck, S. \& Keller, P. (2006). Board Characteristics and Involvement in the Strategic Decision Making: Evidence from Swiss Companies. Journal of Management Studies, 43(5), 1201-1226.

80. Rumelt, R. P. (1982). Diversification strategy and profitability. Strategic Management Journal, 3, 359-369.

81. Sangmi, M. D., \& Jan, S. (2014). Corporate governance policies in Indian commercial Banks: An empirical analysis. IOSR Journal of Business and Management, 16(1), 13-23. Retrieved from http:iosrjournals.org

82. Shleifer, A., \& Vishny, R. B. (1997) A Survey of Corporate Governance, Journal of Finance, 52(2), 737-83.

83. Shukeri, S. N., Shin, O. W., \& Shaari, M. S. (2012). Does board of director's characteristics affect firm performance? Evidence from Malaysian public listed companies. International Business Research, 5(9), 20-127. doi:10.5539/ibr.v5n9p120.

84. Simatupang, L. (2018, July 31). Riset: Perhatian Perbankan pada "Good Corporate Governance" Menurun. Retrieved October 18, 2018, from https:/ekonomi.kompas.com/read/2018/07/31/150600426/riset-perhatian-perbankan-pada-good-corporate-governance-menurun.

85. Stiles, P., (2001). The Impact of the Board on Strategy: An Empirical Examination. Journal of Management Studies, 38(5), 627-650.

86. Syed Fuzi, S. F., Abdul Halim, S. A., \& Julizaerma, M. K. (2016). Board Independence and Firm Performance. Procedia Economics and Finance, $37,460-465$.

87. Tabassum, A. (2015). A Comparative Review of Corporate Governance Practices within Banking Sector (Private, Public and Foreign Banks): An empirical review. Asian Journal of Multidisciplinary Studies. 3(8).

88. Tai, L. (2015). The impact of corporate governance on the efficiency and financial performance of GCC national Banks. Middle East Journal of Business,10(1),12-16. Retrieved from www.mejb.com

89. Vo, D., \& Phan, T. (2013). Corporate governance and firm performance: Empirical evidence from Vietnam. Retrieved from http://www.murdoch. edu.au

90. Wagner, J. A. I.I.I., Stimpert, J. L. \& Fubara, E. I. (1998). Board Composition and Organizational performance: Two Studies of Insider/ outsider Effects. Journal of Management Studies, 35(5), 655-677.

91. Wang, T., \& Hsu, C. (2013). Board composition and operational risk events of financial institutions. Journal of Banking \& Finance, 37, 20422051. doi:10.1016/j.jbankfin.2013.01.027.

92. Weisbach, M. S. (1988). Outside Directors and CEO Turnover, Journal of Financial Economics, 20, $431-460$

93. Wernerfelt, B. (1984). A Resource-Based View of the Firm. Strategic Management Journal, 5(2), 171-180.

94. Withers, M. C. \& Hillman, A. J. (2008). Director Identities and the Role of the Board in Organizational Turnaround, Academy of Management Annual Meeting, Anaheim, CA.

95. Zahra, S. A. \& Pearce, J. A. (1989). Boards of directors and corporate financial performance: A review and integrative model. Journal of Management, 15, 291-334. 